\title{
PEMBELAJARAN KONTEKSTUAL BERBANTUAN PROGRAM GEOMETER'S SKETCHPAD DALAM MENINGKATKAN KEMAMPUAN KONEKSI DAN KOMUNIKASI MATEMATIS SISWA SMP
}

\author{
Oleh: \\ Ishaq Nuriadin \\ Pendidikan Matematika, FKIP UHAMKA \\ ishaq_nuriadin@yahoo.co.id
}

\begin{abstract}
ABSTRAK
Tujuan dari penelitian ini adalah menelaah peningkatan kemampuan koneksi dan komunikasi matematik siswa SMP yang diterapkan pembelajaran kontekstual berbantuan program Geometer's Sketchpad dibandingkan dengan siswa yang diterapkan pembelajaran konvensional, keterkaitan antara kemampuan koneksi dan komunikasi matematis, sikap siswa terhadap pembelajaran kontekstual berbantuan program Geometer's Sketchpad, dan aktivitas siswa selama pembelajaran kontekstual berbantuan program Geometer's Sketchpad berlangsung. Penelitian ini menggunakan desain quasi eksperimen dengan kelompok kontrol pretes dan postes. Kelompok eksperimen memperoleh pembelajaran kontekstual berbantuan program Geometer's Sketchpad dan kelompok kontrol memperoleh pembelajaran konvensional. Untuk mendapatkan data hasil penelitian digunakan instrumen berupa tes kemampuan koneksi, komunikasi matematis dan lembar observasi. Subjek penelitian siswa SMP Negeri 3 Tangerang di Propinsi Banten dengan subjek sampel adalah siswa kelas VII sebanyak dua kelas dari sepuluh kelas yang ada dipilih secara acak. Hasil dari penelitian ini yaitu: (1)Terdapat perbedaan peningkatan kemampuan koneksi dan komunikasi matematik antara kelompok siswa yang belajar dengan menggunakan pendekatan kontekstual dibandingkan dengan siswa yang belajar dengan pendekatan konvensional; (2) Terdapat korelasi positif yang cukup antara kemampuan koneksi dan komunikasi matematik siswa; (3) Pembelajaran dengan menggunakan pendekatan kontekstual memperlihatkan motivasi dan keterlibatan siswa yang baik sehingga terbangun suatu masyarakat belajar dengan suasana yang kondusif.
\end{abstract}

Kata Kunci : Pembelajaran Kontekstual, Geometer's Sketchpad, Kemampuan Koneksi dan Komunikasi Matematis

\begin{abstract}
The objectives of this research are to study the improvement of junior high school student's connection ability and mathematical communication skill treated with contextual learning aided with Geometer's Sketchpad and compared with students with conventional learning; the relationship among connection ability and mathematical communication skill, students' attitude towards contextual learning aided with Geometer's Sketchpad, and the students' activity during the treatment process. The research used a quasi experiment design with pretest and post-test control group. The experiment group was treated with contextual learning
\end{abstract}


aided with Geometer's Sketchpad, while the control group was with conventional learning. The data were gained through connection ability test, mathematical communication skill test, and observation sheet. The subjects of the research were two classes of the seventh grade students of State Junior High School 3 Tangerang, Banten, chosen randomly. The findings show that: (1) there was significant difference of improvement of connection ability and mathematical communication skill between the experiment group and the control group; (2) there was positive correlation between connection ability and mathematical communication skill; (3) the contextual learning promoted students' motivation and involvement in the learning process, so the supportive learning condition could be easily developed.

Keywords: Contextual Learning, Geometer's Sketchpad, Connection Ability, Mathematical Communication Skill

\section{PENDAHULUAN}

Perkembangan ilmu pengetahuan dan teknologi, tidak terlepas dari peranan matematika. Konsep-konsep dalam matematika mampu menjadi sarana untuk meningkatkan komunikasi matematik dan kemampuan untuk mengkoneksikan konsep matematika dalam kehidupan sehari-hari. Bell (1987) mengemukakan bahwa "matematika merupakan ratu dan pelayan ilmu pengetahuan". Berdasarkan pendapat tersebut matematika memiliki peran yang sangat penting dalam berbagai aspek kehidupan manusia. Sesuai dengan pendapat Turmudi (2008:3), bahwa matematika berkaitan erat dengan kehidupan sehari-hari sehingga dengan segera siswa akan mampu menerapkan matematika dalam konteks yang berguna bagi siswa, baik dalam dunia kehidupannya, ataupun dalam dunia kerja kelak.

Data diperlihatkan oleh International Achievement Education (IEA) yang menyebutkan bahwa kemampuan siswa SMP dalam matematika menempati peringkat ke-39 dari 42 negara peserta; kemampuan siswa SMP dalam bidang IPA adalah dalam peringkat ke-40 dari 42 negara peserta (Kusumah, 2008). Telah banyak upaya yang dilakukan untuk meningkatkan prestasi belajar siswa dalam mata pelajaran matematika, baik oleh para guru, maupun para peneliti matematika.

Banyak faktor yang menyebabkan turunya hasil belajar matematika siswa. Antara lain yaitu dari matematika itu sendiri yang objeknya bersifat abstrak. Selain itu, faktor guru, orang tua, siswa, sekolah dan kurikulum turut pula mempengaruhi keberhasilan kegiatan belajar mengajar matematika. Bagi siswa yang mengeluh dan beranggapan bahwa matematika sangat sulit dan menakutkan, mengakibatkan mereka tidak menyenangi bahkan benci pada pelajaran matematika.

Dengan koneksi matematis, para guru dapat membantu siswa-siswa membangun disposisi untuk memanfaatkan hubungan-hubungan dalam memecahkan permasalahan matematis. Melalui koneksi matematik diupayakan agar bagian- 
bagian itu saling berhubungan, sehingga siswa tidak memandang sempit terhadap matematika.

Tujuan siswa memiliki kemampuan koneksi matematik menurut NCTM (2000), agar siswa mampu untuk: (a). Mengenali dan menggunakan koneksi antara gagasangagasan matematika; (b). Memahami bagaimana gagasan-gagasan matematika saling berhubungan dan berdasar pada satu sama lain untuk menghasilkan suatu keseluruhan yang koheren (terpadu); (c). Mengenali dan menerapkan matematika baik di dalam maupun diluar konteks matematika.

Koneksi matematika terbagi ke dalam tiga aspek kelompok koneksi (Wahyudin, 2008: 49), yaitu: (1) aspek koneksi antar topik matematik; (2) aspek koneksi pada pelajaran-pelajaran lain; (3) aspek koneksi di dalam minat-minat dan pengalaman mereka sendiri. Melalui pembelajaran yang menekankan pada saling keterhubungan dari gagasan-gagasan matematis, para siswa tidak saja belajar matematika, tetapi siswa juga belajar tentang kegunaan matematika itu sendiri.

Kemampuan komunikasi adalah kemampuan seseorang untuk menyatakan buah pikiranya dalam bentuk ungkapan kalimat yang bermakna, logis dan sistematis (Sumantri, 2007). Kemampuan berkomunikasi diperlukan dalam pembelajaran matematika agar dapat menyampaikan pemahaman tentang konsep matematika dengan baik.

Baroody (1993:107) menyebutkan bahwa ada lima aspek komunikasi yaitu representasi (representing), mendengar (listening), membaca (reading), diskusi (discussing), dan menulis (writing). Berikut penjelasan sekilas mengenai aspekaspek tersebut: (a).Representasi adalah bentuk baru sebagai hasil transaksi dari suatu masalah atau ide, translasi suatu diagram atau model fisik ke dalam symbol atau kata-kata; (b).Mendengar merupakan mendengar secara hati-hati terhadap pertanyaan teman dalam suatu grup juga dapat membantu siswa mengkonstruksi lebih lengkap pengetahuan matematika dan mengatur strategi jawaban yang lebih efektif; (c).Membaca adalah aktivitas membaca teks secara aktif unuk mencari jawaban atas pertanyaan-pertanyaan yang telah disusun; (d).Diskusi merupakan lanjutan dari membaca dan mendengar, siswa akan mampu menjelaskan dengan baik dalam suatu diskusi apabila mempunyai kemampuan membaca, mendengar, dan mempunyai keberanian; (e).Menulis adalah suatu kegiatan yang dilakukan dengan sadar untuk mengungkapkan dan merefleksikan pikiran. (Irianto, 2003:26).

Menurut Turmudi (2008:55-56) para siswa harus diberikan kesempatan, dorongan, dukungan untuk berbicara, menulis, membaca, dan mendengar dalam kelas matematika memiliki keuntungan ganda, yaitu mereka berkomunikasi untuk belajar matematika dan mereka berkomunikasi secara matematika karena matematika sering diberikan dalam komunikasi simbol, komunikasi tertulis, dan komunikasi lisan yang 
berisi gagasan matematika yang tidak selalu dikenal sebagai bagian penting dalam pendidikan matematika.

Dengan demikian, dapat dikatakan apabila kemampuan koneksi dan komunikasi matematik siswa baik, maka siswa akan cenderung tidak mengalami kesulitan dalam mempelajari matematika selanjutnya, ataupun mempelajari pelajaran lainnya. Pembelajaran yang memungkinkan pengenalan konsep matematika disajikan melalui masalah kontekstual, salah satunya adalah pembelajaran kontekstual (Contextual Teaching and Learning).

Pembelajaran kontekstual merupakan pendekatan dalam pembelajaran yang memungkinkan siswa dapat menguatkan, pengetahuan, dan keterampilan akademik siswa. Menurut Bern dan SeStefano (Suryadi, 2005), pembelajaran kontekstual adalah pembelajaran yang dimulai dengan menghadapkan siswa kedalam suatu permasalahan nyata atau disimulasikan yang menantang, agar siswa dapat termotivasi menyelesaikannya.

Pendekatan kontekstual ini dalam pelaksanaan pembelajaran melibatkan tujuh komponen utama (Trianto, 2007:105-106) yaitu konstruktivisme (Constructivism), bertanya (questioning), menemukan (inquiry), masyarakat belajar (learning community), pemodelan (modelling), refleksi (reflektion) dan penilaian sebenarnya (authentic assessment). Uraian singkat masing-masing komponen dari pembelajaran kontekstual sebagai berikut: (1).Konstruktivisme (Constructivism). Matematika dikonstruksi oleh pemahaman siswa dan siswa secara aktif mengkonstruksi matematika yang difasilitasi oleh guru, bukan transfer guru ke dalam otak siswa;(2).Menemukan (Inquiry). Pembelajaran inquiry, memberikan kesempatan kepada siswa untuk terlibat aktif melakukan investigasi untuk menemukan sendiri konsep dan prinsip-prinsip;(3).Bertanya (Questioning). Bertanya dalam pembelajaran dipandang sebagai kegiatan guru untuk mendorong, membimbing dan menilai kemampuan berpikir siswa; (4).Masyarakat Belajar (Learning Community). Masyarakat belajar dalam pembelajaran terwujud dalam pembentukan kelompok kecil dan kelompok besar, mendatangkan ahli, berkerja dengan kelas sederajat, bekerja dengan kelas diatasnya dan bekerja dengan masyarakat;(5).Pemodelan (Modeling). Pemodelan yang dimaksud adalah dalam sebuah pembelajaran keterampilan atau pengetahuan tertentu, ada model yang bisa di tiru; (6). Refleksi(Reflection). Refleksi adalah cara berpikir tentang apa yang baru dipelajari atau berpikir ke belakang tentang apa yang kita lakukan dimasa yang lalu.

Pembelajaran matematika lebih bersifat latihan mengerjakan banyak soal yang hampir sama dengan contoh, akibatnya kemampuan koneksi dan komunikasi siswa kurang berkembang. Hal ini, didukung laporan dari TIMMS (2003) bahwa penekanan pembelajaran matematika di Indonesia lebih banyak menekankan kepada keterampilan dasar, beberapa pemahaman konsep dan latihan, dan sedikit sekali mengenai kemampuan penalaran, komunikasi, aplikasi dalam kehidupan nyata dan 
lain sebagainya. Padahal, kemampuan koneksi dan komunikasi matematik siswa merupakan bagian esensial yang harus dikembangkan sejak dini.

Geometri merupakan salah satu dari materi yang diajarkan di tingkat Sekolah Menengah Pertama (SMP), geometri diajarkan mulai dari tingkat SD sampai SMA. Menurut Jiang (2006) salah satu bagian dari matematika yang sangat lemah diserap oleh siswa di sekolah adalah geometri. Salah satu cara yang efektif untuk menambah pemahaman dan meningkatkan kemampuan koneksi dan komunikasi dalam memecahkan persoalan matematika dengan menggunakan teknologi.

Penggunaan Teknologi salah satu cara untuk meningkatkan motivasi belajar siswa. NCTM (Tajudin et al, 2007) menyatakan bahwa teknologi adalah sesuatu yang sangat esensial dalam proses belajar mengajar matematika, dengan menggunakan teknologi proses belajar mengajar matematika menjadi berpusat pada siswa. Pada penelitian ini menggunakan teknologi komputer Program Geometer's Sketchpad . Guru bisa meminta siswa untuk mengeksplorasi, investigasi, interpretasi, representasi serta memecahkan masalah matematika dengan software yang cukup interaktif (King \& Schattschneider dalam Shamatha, 2004).

Ada beberapa pertimbangan tentang penggunaan Dynamic Geometry Software seperti Geometer's Sketchpad dalam pembelajaran matematika, khususnya pada pokok bahasan segitiga. Hoehn (Lam, 2007) juga mengatakan bahwa siswa yang diajarkan geometri dengan GSP dapat membuktikan teorema-teorema yang ada pada geometri. Selain itu, pada program GSP mampu membantu siswa dalam memanfaatkan penggunaan penggaris, busur, dan jangka.

Pembelajaran kontekstual berbantuan program GSP diharapkan menjadi salah satu solusi untuk meningkatkan kemampuan koneksi dan komunikasi matematik siswa. Berkaitan dengan penggunaan alat bantu dalam proses belajar mengajar geometri yaitu GSP, maka diduga ada peningkatkan kemampuan koneksi dan komunikasi matematik siswa SMP melalui pembelajaran kontekstual dengan berbantuan program Geometer's Sketchpad.

\section{Rumusan Masalah penelitian}

Berdasarkan uraian di atas terdapat beberapa rumusan masalah sebagai berikut:

a. Apakah terdapat peningkatan kemampuan koneksi matematika siswa yang memperoleh pembelajaran kontekstual berbantuan program Geometer's Sketchpad lebih baik dibandingkan dengan siswa yang memperoleh pembelajaran matematika secara konvensional?

b. Apakah terdapat peningkatan kemampuan komunikasi matematika siswa yang memperoleh pembelajaran kontekstual berbantuan program Geometer's Sketchpad lebih baik dibandingkan dengan siswa yang memperoleh pembelajaran matematika secara konvensional? 
c. Apakah ada kaitan yang signifikan antara kemampuan koneksi dan kemampuan komunikasi matematika siswa?

d. Bagaimana aktivitas selama proses belajar mengajar siswa yang memperoleh pembelajaran kontekstual berbantuan program Geometer's Sketchpad dan siswa yang memperoleh pembelajaran matematika secara konvensional?

\section{Tujuan Penelitian}

Tujuan penelitian ini adalah sebagai berikut: (1). Membandingkan peningkatan kemampuan koneksi matematis siswa yang memperoleh pembelajaran kontekstual berbantuan program Geometer's Sketchpad lebih baik dibandingkan dengan siswa yang memperoleh pembelajaran matematika secara konvensional. (2). Membandingkan peningkatan kemampuan komunikasi matematika siswa yang memperoleh pembelajaran kontekstual berbantuan program Geometer's Sketchpad lebih baik dibandingkan dengan siswa yang memperoleh pembelajaran matematika secara konvensional. (3) Mengetahui keterkaitan antara kemampuan koneksi dan komunikasi matematik siswa. (4). Mengetahui sikap siswa terhadap pembelajaran kontekstual berbantuan program Geometer's Sketchpad. (5). Mengetahui aktivitas selama proses belajar mengajar siswa yang memperoleh pembelajaran kontekstual berbantuan program Geometer's Sketchpad dan siswa yang memperoleh pembelajaran matematika secara konvensional.

\section{METODE PENELITIAN}

Penelitian ini menggunakan metode quasi eksperimen, yang menerapkan pembelajaran kontekstual dengan berbantuan Program Sketchpad. Disain penelitian berbentuk Pre-test Post-test Control Group Design dapat digambarkan sebagai berikut:

\section{Tabel 2.1 Desain Penelitian}

$\begin{array}{llll}\text { Treatment Group } & \mathrm{O}_{1} & \mathrm{X}_{1} & \mathrm{O}_{2} \\ \text { Control Group } & \mathrm{O}_{1} & \mathrm{X}_{2} & \mathrm{O}_{2}\end{array}$

Keterangan:

$Q_{1} \quad$ : Pretes.

$Q_{2} \quad$ : Postes.

$X_{1} \quad$ : Pembelajaran kontekstual dengan bantuan program Geometer's Sketchpat.

$X_{2} \quad$ : Pembelajaran konvensional.

Populasi dalam penelitian ini siswa SMP di Kota Tangerang Propinsi Banten, dengan populasi terjangkau siswa SMP Negeri 3 Tangerang kelas VII. Sampel penelitian terdiri dari 2 kelas, yaitu kelas eksperimen dan kelas kontrol dipilih secara diundi dari 8 kelas yang ada. Penentuan sampel dilakukan dengan menggunakan teknik "Claster Random Sampling". 
Instrumen yang digunakan berupa tes. Butir soal tes tersebut harus diuji validitas, reliabilitas, tingkat kesukaran dan daya pembeda. Skala sikap digunakan untuk mengetahui sikap siswa terhadap pembelajaran matematika dengan pembelajaran kontekstual berbantuan program Geometer's Sketchpad yang diberikan. Teknik analisis data menggunakan rumus uji-t, untuk menguji hipotesis menggunakan rumus statistik untuk menguji kesamaan dua rata-rata.

\section{HASIL PENELITIAN DAN PEMBAHASAN}

\section{Hasil Penelitian}

\section{Hasil Tes Kemampuan Komunikasi dan Koneksi Matematis Siswa Kelompok Eksperimen dan Kontrol}

Hasil tes matematika terdiri dari skor pretes dan postes. Untuk mengetahui peningkatan terhadap kemampuan komunikasi dan koneksi matematik siswa dilihat dari skor pretes, postes, dan gain yang dihitung berdasarkan gain ternormalisasi (normalized gain).

Kemampuan komunikasi dan koneksi matematis siswa pada kelompok eksperimen dan kontrol sebelum dan sesudah perlakuan pada siswa dapat dilihat dari skor pretes dan postes.

Tabel 3.1 Skor Tertinggi, Skor Terendah, Skor Rata-rata, dan Deviasi Standar Pretes pada Kelompok Eksperimen dan Kontrol

\begin{tabular}{ccccccccccc}
\hline \multirow{2}{*}{ Aspek } & Skor & \multicolumn{3}{c}{ Kelompok Eksperimen } & \multicolumn{3}{c}{ Kelompok Kontrol } \\
\cline { 5 - 11 } & Ideal & $\boldsymbol{X}_{\text {min }}$ & $\boldsymbol{X}_{\text {maks }}$ & $\bar{X}$ & $\boldsymbol{S}$ & $\boldsymbol{X}_{\text {min }}$ & $\boldsymbol{X}_{\text {maks }}$ & $\bar{X}$ & $\mathbf{S}$ \\
\hline $\begin{array}{c}\text { Kemampuan } \\
\text { Komunikasi Matematis }\end{array}$ & 24 & 1 & 10 & 4,80 & 2,19 & 1 & 10 & 4,03 & 2,08 \\
$\begin{array}{c}\text { Kemampuan Koneksi } \\
\text { Matematis }\end{array}$ & 27 & 2 & 13 & 5,43 & 2,33 & 2 & 13 & 6,43 & 2,62 \\
\hline
\end{tabular}

Dari Tabel di atas dapat diketahui bahwa rata-rata skor kemampuan komunikasi dan koneksi matematis pada kelompok eksperimen dan kontrol setelah diolah tidak berbeda secara signifikan.

Tabel 3.2 Skor Tertinggi, Skor Terendah, Skor Rata-rata, dan Deviasi Standar Postes pada Kelompok Eksperimen dan Kontrol

\begin{tabular}{|c|c|c|c|c|c|c|c|c|c|}
\hline \multirow{2}{*}{ Aspek } & \multirow{2}{*}{ Skor Ideal } & \multicolumn{4}{|c|}{ Kelompok Eksperimen } & \multicolumn{4}{|c|}{ Kelompok Kontrol } \\
\hline & & $X_{\min }$ & $X_{\text {maks }}$ & $\bar{X}$ & $S$ & $X_{\min }$ & $X_{\text {maks }}$ & $\bar{X}$ & $\mathbf{S}$ \\
\hline $\begin{array}{l}\text { Kemampuan } \\
\text { Komunikasi } \\
\text { Matematis }\end{array}$ & 24 & 11 & 22 & 17,29 & 3,69 & 4 & 16 & 9,14 & 4,09 \\
\hline $\begin{array}{c}\text { Kemampuan } \\
\text { Koneksi } \\
\text { Matematis }\end{array}$ & 27 & 6 & 23 & 14,94 & 5,47 & 5 & 18 & 11,63 & 4,17 \\
\hline
\end{tabular}


Dari tabel dapat dikatakan bahwa kemampuan komunikasi dan koneksi matematis siswa pada kelompok eksperimen ditinjau dari skor postes lebih baik daripada kelompok kontrol.

Tabel 3.3 Gain Ternormalisasi Kelompok Eksperimen dan Kontrol

\begin{tabular}{ccccc}
\hline \multirow{2}{*}{ Aspek } & \multicolumn{2}{c}{ Kelompok Eksperimen } & \multicolumn{2}{c}{ Kelompok Kontrol } \\
\cline { 2 - 5 } & $\begin{array}{c}\text { Rata-rata } \\
\text { Gain } \\
\text { Ternormalisasi }\end{array}$ & Kategori & $\begin{array}{c}\text { Rata-rata } \\
\text { Gain } \\
\text { Ternormalisasi }\end{array}$ & Kategori \\
\hline $\begin{array}{c}\text { Kemampuan } \\
\text { Komunikasi Matematis } \\
\text { Kemampuan Koneksi } \\
\text { Matematis }\end{array}$ & 0,66 & Sedang & 0,26 & Rendah \\
\hline
\end{tabular}

Berdasarkan Tabel terlihat kelompok yang diberikan pembelajaran dengan menggunakan pendekatan kontekstual berada pada kategori sedang, dan rata-rata gain ternormalisasi kemampuan komunikasi dan koneksi matematis siswa pada kelompok kontrol yaitu kelompok siswa yang diberikan pembelajaran konvensional berada pada kategori rendah.

Tabel 3.4 Rekapitulasi Skor Rata-rata Gain Ternormalisasi Kemampuan Komunikasi Matematik Siswa Kelompok Eksperimen

\begin{tabular}{|c|c|c|c|c|c|}
\hline $\begin{array}{l}\text { No } \\
\text { Soal }\end{array}$ & $\begin{array}{l}\text { Rata-rata } \\
\text { Skor } \\
\text { Pretes }\end{array}$ & $\begin{array}{l}\text { Rata-rata } \\
\text { Skor } \\
\text { Postes }\end{array}$ & $\begin{array}{c}\text { Rata-rata } \\
\text { Skor Gain } \\
\text { Ternormalisasi }\end{array}$ & Kategori & $\begin{array}{l}\text { Jenis Kemampuan } \\
\text { Komunikasi }\end{array}$ \\
\hline 1 & 1,86 & 3,57 & 0,79 & Tinggi & $\begin{array}{l}\text { Menuliskan jawaban dengan } \\
\text { bahasa sendiri dan membuat } \\
\text { model matematika }\end{array}$ \\
\hline 2 & 1,31 & 2,71 & 0,52 & Sedang & $\begin{array}{l}\text { Mengambar diagram dan } \\
\text { membuat model matematika }\end{array}$ \\
\hline 3 & 0,34 & 2,69 & 0,64 & Sedang & $\begin{array}{l}\text { Menggambar diagram, membuat } \\
\text { model matematika, menuliskan } \\
\text { jawaban dengan bahasa sendiri } \\
\text { dan memberikan penjelasan atas } \\
\text { jawaban }\end{array}$ \\
\hline 4 & 0,43 & 2,60 & 0,61 & Sedang & $\begin{array}{l}\text { Menggambar diagram, } \\
\text { menuliskan jawaban dengan } \\
\text { bahasa sendiri dan memberikan } \\
\text { penjelasan atas jawaban }\end{array}$ \\
\hline 5 & 0,11 & 2,57 & 0,63 & Sedang & $\begin{array}{l}\text { Menuliskan jawaban dengan } \\
\text { bahasa sendiri dan memberikan } \\
\text { penjelasan atas jawaban }\end{array}$ \\
\hline 6 & 1,03 & 3,17 & 0,72 & Tinggi & $\begin{array}{l}\text { Membuat model matematika, } \\
\text { menuliskan jawaban dalam } \\
\text { bahasa sendiri dan memberikan } \\
\text { penjelasan atas jawaban }\end{array}$ \\
\hline Jumlah & 5,08 & 17,31 & 0,65 & Sedang & Keseluruhan \\
\hline
\end{tabular}


Dari Tabel di atas dapat dilihat bahwa peningkatan kemampuan komunikasi tertinggi yaitu pada jenis kemampuan membuat model matematika, menuliskan jawaban dengan bahasa sendiri dan memberikan penjelasan atas jawaban dengan besarnya peningkatan 0,79 dan berada dalam kategori tinggi.

Tabel 3.5 Rekapitulasi Skor Rata-rata Gain Ternormalisasi Kemampuan Koneksi Matematis Siswa Kelompok Eksperimen

\begin{tabular}{|c|c|c|c|c|c|}
\hline $\begin{array}{l}\text { No } \\
\text { Soal }\end{array}$ & $\begin{array}{l}\text { Rata-rata } \\
\text { Skor } \\
\text { Pretes }\end{array}$ & $\begin{array}{l}\text { Rata-rata } \\
\text { Skor } \\
\text { Postes }\end{array}$ & $\begin{array}{c}\text { Rata-rata } \\
\text { Skor Gain } \\
\text { Ternormalisasi }\end{array}$ & Kategori & Jenis Kemampuan Koneksi \\
\hline 1 & 1,22 & 3,17 & 0,41 & Sedang & $\begin{array}{l}\text { Kemampuan mengaplikasikan } \\
\text { konsep matematika dalam } \\
\text { bidang ilmu yang lain. }\end{array}$ \\
\hline 2 & 3,14 & 4,71 & 0,55 & Sedang & $\begin{array}{l}\text { Kemampuan mengaplikasikan } \\
\text { konsep matematika dalam } \\
\text { kehidupan sehari-hari. }\end{array}$ \\
\hline 3 & 0,34 & 1,54 & 0,45 & Sedang & $\begin{array}{l}\text { Kemampuan memahami } \\
\text { hubungan antar topik } \\
\text { matematika. }\end{array}$ \\
\hline 4 & 0 & 1,11 & 0,37 & Sedang & $\begin{array}{l}\text { Kemampuan mengaplikasikan } \\
\text { konsep matematika dalam } \\
\text { kehidupan sehari-hari dan } \\
\text { kemampuan memahami } \\
\text { hubungan antar topik } \\
\text { matematika. }\end{array}$ \\
\hline 5 & 0,29 & 1,89 & 0,59 & Sedang & $\begin{array}{l}\text { Kemampuan dalam mencari } \\
\text { hubungan suatu representasi } \\
\text { konsep dan prosedur dan } \\
\text { kemampuan mengaplikasikan } \\
\text { konsep matematika dalam } \\
\text { kehidupan sehari-hari. }\end{array}$ \\
\hline 6 & 0,43 & 2,51 & 0,37 & Sedang & $\begin{array}{l}\text { Kemampuan dalam mencari } \\
\text { hubungan suatu representasi } \\
\text { konsep dan prosedur dan } \\
\text { kemampuan mengaplikasikan } \\
\text { konsep matematika dalam } \\
\text { kehidupan sehari-hari. }\end{array}$ \\
\hline Jumlah & 5,42 & 14,93 & 0,44 & Sedang & Keseluruhan \\
\hline
\end{tabular}

Dari Tabel dapat dilihat bahwa dari keenam soal tes kemampuan koneksi matematis yang diberikan, besarnya peningkatan dari rata-rata skor gain semuanya berada pada kategori sedang dimana nilai rata-rata skor gain ternormalisasi berkisar antara 0,77 sampai dengan 0,59. 


\section{Uji Perbedaan Rata-rata Skor Pretes, Postes, dan Gain Kemampuan Komunikasi Matematis Siswa pada Kelompok Eksperimen dan Kontrol}

Hasil uji perbedaan rata-rata skor pretes kemampuan komunikasi dan koneksi matematis siswa kelompok eksperimen dan kontrol dapat disimpulkan bahwa kemampuan komunikasi dan koneksi matematis siswa pada kelas eksperimen dan kontrol relatif sama atau dapat dikatakan tidak terdapat perbedaan kemampuan pada kedua kelompok tersebut.

Tabel 3.12 Hasil Uji Perbedaan Rata-rata Skor Pretes Kelompok Eksperimen dan Kontrol

\begin{tabular}{|c|c|c|c|c|c|c|c|c|c|}
\hline \multirow{2}{*}{ Aspek } & \multirow{2}{*}{$\begin{array}{l}\text { Skor } \\
\text { Maks }\end{array}$} & \multicolumn{3}{|c|}{$\begin{array}{c}\text { Kelompok } \\
\text { Eksperimen }\end{array}$} & \multicolumn{3}{|c|}{$\begin{array}{c}\text { Kelompok } \\
\text { Kontrol }\end{array}$} & \multirow{2}{*}{$t_{\text {hitung }}$} & \multirow{2}{*}{$t_{\text {tabel }}$} \\
\hline & & $\bar{x}$ & $s$ & $s^{2}$ & $\bar{x}$ & $s$ & $s^{2}$ & & \\
\hline $\begin{array}{c}\text { Komunikasi } \\
\text { Matematis }\end{array}$ & 24 & 4,8 & 2,188 & 4,789 & 4,029 & 2,077 & 4,313 & 1,515 & 2,46 \\
\hline $\begin{array}{c}\text { Koneksi } \\
\text { Matematis }\end{array}$ & 27 & 5,43 & 2,333 & 5,445 & 6,429 & 2,622 & 6,873 & $-1,686$ & 2,46 \\
\hline
\end{tabular}

Hasil uji perbedaan rata-rata skor postes kemampuan komunikasi dan koneksi matematis siswa kelompok eksperimen dan kontrol disimpulkan bahwa kemampuan komunikasi dan koneksi matematik siswa pada kelas eksperimen dan kontrol tidak sama (berbeda) secara signifikan atau dapat dikatakan bahwa kemampuan komunikasi dan koneksi matematik siswa pada kelompok eksperimen lebih baik dari kelompok kontrol.

Tabel 3.13 Hasil Uji Perbedaan Rata-rata skor Postes Kelompok Eksperimen dan Kontrol

\begin{tabular}{|c|c|c|c|c|c|c|c|c|c|}
\hline \multirow[t]{2}{*}{ Aspek } & \multirow{2}{*}{$\begin{array}{l}\text { Skor } \\
\text { Maks }\end{array}$} & \multicolumn{3}{|c|}{$\begin{array}{c}\text { Kelompok } \\
\text { Eksperimen }\end{array}$} & \multicolumn{3}{|c|}{$\begin{array}{c}\text { Kelompok } \\
\text { Kontrol }\end{array}$} & \multirow{2}{*}{$t_{\text {hitung }}$} & \multirow{2}{*}{$t_{\text {tabe }}$} \\
\hline & & $\bar{x}$ & $s$ & $s^{2}$ & $x$ & $s$ & $s^{2}$ & & \\
\hline $\begin{array}{l}\text { Komunikasi } \\
\text { Matematik }\end{array}$ & 24 & 17,29 & 3,699 & 13,69 & 9,14 & 4,1 & 16,81 & 8,726 & 2,46 \\
\hline $\begin{array}{c}\text { Koneksi } \\
\text { Matematik }\end{array}$ & 27 & 14,94 & 5,466 & 29,89 & 11,63 & 4,17 & 17,38 & 2,852 & 2,46 \\
\hline
\end{tabular}

Hasil hasil uji perbedaan rata-rata untuk gain kemampuan komunikasi dan koneksi matematis siswa pada kelompok eksperimen dan kontrol disimpulkan bahwa kemampuan komunikasi dan koneksi matematis siswa pada kelas eksperimen dan kontrol berbeda secara signifikan atau dapat dikatakan bahwa kemampuan komunikasi dan koneksi matematik siswa pada kelompok eksperimen lebih baik dari kelompok kontrol. 
Tabel 3.14 Hasil Uji Perbedaan Rata-rata Skor Gain Ternormalisasi Kelompok Eksperimen dan Kontrol

\begin{tabular}{|c|c|c|c|c|c|c|c|c|c|}
\hline \multirow{2}{*}{ Aspek } & \multirow{2}{*}{$\begin{array}{l}\text { Skor } \\
\text { Maks }\end{array}$} & \multicolumn{3}{|c|}{$\begin{array}{c}\text { Kelompok } \\
\text { Eksperimen } \\
\end{array}$} & \multicolumn{3}{|c|}{$\begin{array}{c}\text { Kelompok } \\
\text { Kontrol }\end{array}$} & \multirow{2}{*}{$t_{\text {hitung }}$} & \multirow{2}{*}{$t_{\text {tabel }}$} \\
\hline & & $\bar{x}$ & $s$ & $s^{2}$ & $\bar{x}$ & $s$ & $s^{2}$ & & \\
\hline $\begin{array}{c}\text { Komunikasi } \\
\text { Matematis }\end{array}$ & 24 & 0,665 & 0,158 & 0,025 & 0,258 & 0,174 & 0,030 & 8,726 & 2,46 \\
\hline $\begin{array}{c}\text { Koneksi } \\
\text { Matematis }\end{array}$ & 27 & 0,450 & 0,231 & 0,053 & 0,299 & 0,207 & 0,043 & 2,904 & 2,46 \\
\hline
\end{tabular}

\section{Korelasi antara Kemampuan Komunikasi dan Koneksi Matematis Siswa}

Dari hasil perhitungan, diperoleh koefesien korelasi Pearson untuk kemampuan komunikasi dan koneksi matematis siswa sebesar 0,510 pada kelompok eksperimen dan ternyata besarnya korelasi ini signifikan pada $\alpha=0,01$. Nilai $r$ yang diperoleh menunjukkan besarnya korelasi ini cukup.

Assosiasi antara kemampuan komunikasi dan koneksi matematis disimpulkan bahwa terdapat assosiasi yang cukup antara kemampuan komunikasi matematik dan koneksi matematik siswa. Artinya sebagian besar siswa yang memiliki kemampuan tinggi pada komunikasi juga memiliki kemampuan yang tinggi pula di koneksi matematis, demikian juga siswa yang berkemampuan cukup dan rendah.

\section{Hasil Observasi}

Penerapan pembelajaran kontekstual berbantuan program Geometer's Sketchpad ini mampu memberikan suatu suasana pembelajaran baru bagi siswa sehingga pembelajaran lebih kondusif. Keadaan yang kondusif ini, ditunjukkan dengan meningkatnya aktivitas diskusi siswa serta meningkatnya sikap positif siswa terhadap pembelajaran matematika. Pada pembelajaran biasa, pertama guru menjelaskan materi, dan memberikan contoh soal dan penyelesaiannya. Siswa menyimak penjelasan guru dengan seksama, jika dari materi yang disampaikan guru kurang jelas siswa diizinkan untuk mengajukan pertanyaan. Setelah kegiatan ini selesai, siswa diberikan soal-soal latihan yang dikerjakan siswa secara individu. Pada saat siswa mengerjakan soal latihan, guru berkeliling memberikan bantuan kepada siswa yang mengalami masalah. Aktivitas siswa pada kelas ini, cenderung lebih pasif dibandingkan dengan kelas yang belajar dengan menggunakan pendekatan kontekstual. 


\section{Pembahasan}

\section{Kemampuan Komunikasi dan Koneksi Matematis Siswa}

Berdasarkan hasil pretes, kedua kelompok siswa yaitu kelompok eksperimen dan kontrol memiliki kemampuan komunikasi dan koneksi matematik awal yang sama (tidak berbeda secara signifikan). Akan tetapi setelah terjadinya perlakuan, dari data hasil postes kedua kelompok siswa memiliki kemampuan komunikasi dan koneksi yang berbeda secara signifikan. Karena pembelajaran dengan menggunakan pendekatan kontekstual berbantuan program Geometer's Sketchpad ini merupakan suatu pendekatan pembelajaran yang lebih menekankan pada keaktifan siswa agar mampu merekonstruksi pengetahuan mereka sendiri.

\section{Hubungan antara Kemampuan Komunikasi dan Koneksi Matematis}

Dari uji satatistik terhadap hipotesis 3, tentang terdapatnya korelasi positif antara kemampuan komunikasi dan koneksi matematik. Dari hasil perhitungan assosiasi juga ditemukan bahwa terdapat kaitan yang cukup signifikan antara kemampuan komunikasi dan koneksi matematik siswa pada tingkat signifikansi $\alpha=0,01$ dan assosiasi tersebut berada pada penggolongan cukup dengan tingkat keeratan hubungan antara kemampuan komunikasi dan koneksi matematis sebesar 26,01\% dan sisanya 73,99\% dintentukan oleh kemampuan matematis lain seperti penalaran, kritis, kreatif dan lain sebagainya.

\section{Aktivitas Siswa Selama Proses Pembelajaran}

Berdasarkan data hasil observasi selama proses pembelajaran dengan pendekatan kontekstual berbantuan program Geometer's Sketchpad diketahui aktivitas siswa untuk memperhatikan penjelasan guru atau siswa lainnya, mempelajari materi, bekerja sama, berdiskusi, mengemukakan pendapat secara lisan dan tampil mengemukakan pendapatnya di depan kelas, serta membuat kesimpulan materi yang telah dipelajari pada umumnya adalah baik, artinya siswa terlibat secara aktif dalam pembelajaran, guru hanya berperan sebagai fasilitator, pembimbing dan memberikan motivasi kepada siswa untuk belajar lebih aktif dan kritis dalam menyelesaikan permasalahan.

\section{KESIMPULAN}

Kesimpulan dalam penelitian ini sebagai berikut: (1)Terdapat perbedaan peningkatan kemampuan komunikasi dan koneksi matematis antara kelompok siswa yang belajar dengan menggunakan pendekatan kontekstual berbantuan program Geometer's Sketchpad dibandingkan dengan siswa yang belajar dengan pendekatan konvensional; (2) Terdapat korelasi positif yang cukup antara kemampuan komunikasi dan koneksi matematis siswa; (3) Pembelajaran dengan menggunakan pendekatan kontekstual berbantuan 
program Geometer's Sketchpad memperlihatkan motivasi dan keterlibatan siswa, sehingga terbangun suatu masyarakat belajar yang baik.

\section{DAFTAR PUSTAKA}

Baroody, A.J., (1993). Problem Solving Reasoning and Communicating, K-8: Helping Children Think Mathematically. Macmillan Publishing Company, a division of Macmillan, Inc.

Bell, F.H.(1987). Teaching and Learning Mathematics (In Secondary Schools). University of Pittsburgh.

Irianto Ansari, Bansu. (2003). Menumbuhkembangkan Kemampuan Pemahaman dan Komunikasi Matematika Siswa SMU Melalui Strategi Think-Talk-Write. Disertasi. Bandung: Program Pasca Sarjana UPI.

Jiang, Z. (2008), Explorations and Reasoning in the Dynamic Geometry Environment. [Online]. Tersedia: http://atcm.mathandtech.org/EP2008/papers_full/2412008_15336.pdf. [25 Januari 2009].

Kusumah, Y. S. (2008). Konsep, Pengembangan, dan Implementasi KomputerBased Learning Dalam Peningkatan Kemampuan High-Order Mathematical Thinking. Makalah disajikan dalam Pengukuhan Guru Besar Pendidikan Matematika FMIPA UPI Bandung.

Lam, T. T. (2007). Use of Geometer's Sketchpad (GSP) to Teach Mechenics Concept in A Level Mathematics.[Online]. Tersedia: http://www.any2any.org/EPATCM/EP/2004/2004C141/fullpaper.pdf. [17 Januari 2008.

NCTM, (2000) Curriculum and Evaluation Standards for School Mathematics. United States of America: The National Council of Teachers of Mathematics, Inc.

Shamata, H. J. (2004). Technology-Supported Mathematics Activities Situated Within an Effective Learning Environment Theoretical Framework. [Online]. Tersedia: http://www.citejournal.org/vol3/iss4/mathematics/article1.cfm [16 Januari 2009].

Sumantri, Mulyani. (2007). Materi Pokok Perkembangan Peserta Didik. Jakarta: Universitas Terbuka.

Suryadi, D. (2005). Penggunaan Pendekatan Pembelajaran Tidak Langsung serta pendekatan Gabungan Langsung dan Tidak Langsung dalam Rangka Meningkatkan Kemampuan Berpikir Matematik Timgkat Tinggi siswa. Bandung: PPS UPI.

Tajudin, et all. (2007). Effect of Use of Graphic Calculators on Performance in Teaching and Learning Mathematics. Journal Education.

TIMSS, (2003). International Students Achievement In Mathematics. [Online]. Tersedia: http://timss:bc.edu/timss2003i/pdf/T03imath01.pdf. [27 Desember 2008]. 
Trianto, (2007). Model-Model pembelajaran Inovatif Berorientasi Konstruktivistik (Konsep, Landasan Teoritis-Praktis dan implementasinya). Jakarta: Prestasi Pustaka.

Turmudi. (2008). Landasan Filsafat dan Teori pembelajaran Matematika (berparadigma Eksploratif dan investigative). Bandung: PT. Leuser Cita Pustaka.

Wahyudin. (2008). Pembelajaran dan Model-model pembelajaran (Pelengkap untuk Meningkatkan Kompetensi Pedagogis Para Guru dan Calon guru Propesional). 